\title{
Data report: Mg/Ca values of Globorotalia tumida from early Pliocene to present, Site U1338'
}

\author{
Heather L. Ford, ${ }^{2,3}$ A. Christina Ravelo, ${ }^{2}$ Briana Ramirez, ${ }^{4}$ Taylor Akers, ${ }^{2}$ and Olivia Krzeminski ${ }^{2}$
}

\section{Chapter contents}

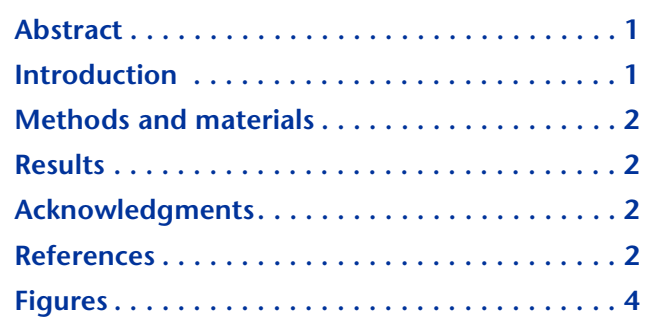

${ }^{1}$ Ford, H.L., Ravelo, A.C., Ramirez, B., Akers, T., and Krzeminski, O., 2018. Data report: $\mathrm{Mg} / \mathrm{Ca}$ values of Globorotalia tumida from early Pliocene to present, Site U1338. In Pälike, H., Lyle, M., Nishi, H., Raffi, I., Gamage, K., Klaus, A., and the Expedition 320/321 Scientists, Proceedings of the Integrated Ocean Drilling Program, 320/321: Tokyo (Integrated Ocean Drilling Program Management International, Inc.).

doi:10.2204/iodp.proc.320321.220.2018

${ }^{2}$ Department of Ocean Sciences, University of California Santa Cruz, 1156 High Street, Santa Cruz CA 95064, USA.

${ }^{3}$ Present address: Department of Earth Sciences, University of Cambridge, Downing Street, Cambridge, Cambridgeshire CB2 3EQ, United Kingdom.HLF40@cam.ac.uk

${ }^{4}$ Department of Physical and Environmental Science, St. Mary's University, One Camino Santa Maria, San Antonio TX 78228, USA.

\section{Abstract}

The equatorial Pacific thermocline is a critical component in determining the ocean-atmosphere interactions of the tropics. During the Pliocene warm period, the tropical thermocline was warm and/or deep and shoaled toward present day. Here we use $\mathrm{Mg} / \mathrm{Ca}$ values of subsurface-dwelling Globorotalia tumida to reconstruct subsurface temperatures at Integrated Ocean Drilling Program Site U1338.

\section{Introduction}

The tropical thermocline is a key feature in the coupled ocean-atmosphere system of the equatorial Pacific. In the eastern equatorial Pacific (Fig. F1), a shallow thermocline and upwelling favorable winds bring cold, nutrient-rich water to the surface (Fiedler and Talley, 2006). In contrast, the Western Pacific Warm Pool is characterized by warm sea-surface temperatures and a deep thermocline. During the Pliocene warm period ( 3 to $5 \mathrm{Ma}$ ), subsurface temperatures were warm across the equatorial Pacific, suggesting the tropical thermocline was warm and/or deep (Ford et al., 2012, 2015; Steph et al., 2006, 2010).

There are key differences in the subsurface temperature evolution between the eastern and western Pacific. In the eastern equatorial Pacific, subsurface temperatures steeply cooled by $\sim 3^{\circ} \mathrm{C}$ between 4.0 and $4.8 \mathrm{Ma}$ and gradually cooled an additional $\sim 2^{\circ} \mathrm{C}$ toward the present day (Ford et al., 2012; Steph et al., 2006, 2010). In comparison, subsurface temperatures gradually cooled $\sim 3^{\circ} \mathrm{C}$ from the Pliocene to the present day (Ford et al., 2015). Integrated Ocean Drilling Program (IODP) Site U1338 $\left(2^{\circ} 30.469^{\prime} \mathrm{N}\right.$, $117^{\circ} 58.178^{\prime} \mathrm{W} ; 4200 \mathrm{~m}$ water depth) is ideally situated to examine the spatial pattern of east vs. west subsurface temperature evolution because it is located just west of the eastern equatorial Pacific cold tongue region (Fig. F1).

Here we reconstruct subsurface temperatures over the last $5 \mathrm{My}$ at Site U1338. We use the $\mathrm{Mg} / \mathrm{Ca}$ values for Globorotalia tumida to reconstruct thermocline conditions because its calcification depth is approximately $100 \mathrm{~m}$, independent of thermocline depth (Rincón-Martínez et al., 2011). We find subsurface temperatures were warm during the early Pliocene ( $\sim 5 \mathrm{Ma})$ and cooled toward 
the present day, consistent with other records from the eastern equatorial Pacific.

\section{Methods and materials}

A low-resolution (approximately one sample every $\sim 60,000$ y) subsurface temperature record was generated from the $\mathrm{Mg} / \mathrm{Ca}$ values of Globorotalia tumida. G. tumida were picked from the $355-425 \mathrm{~m}$ size fraction. Approximately 15 individuals $(N=4-29)$ were crushed and cleaned for minor elemental analyses. Samples were cleaned using a standard protocol that included repetitive Milli-Q water and methanol rinses, oxidative and reductive cleaning steps, and a weak acid leach (Martin and Lea, 2002; Rosenthal and Lohmann, 2002). Cleaned samples were measured on a PerkinElmer Optima 8300 inductively coupled plasma-optical emission spectrometer (ICPOES) (Wara et al., 2003). Long-term $\mathrm{Mg} / \mathrm{Ca} \mathrm{mmol} /$ mol reproducibility for a liquid consistency standard and foraminifer standard are $3.32 \pm 0.030 \mathrm{mmol} / \mathrm{mol}$ $(1 \sigma ; N=434)$ and $3.75 \pm 0.180 \mathrm{mmol} / \mathrm{mol}(1 \sigma ; N=$ $115)$, respectively. $\mathrm{Mg} / \mathrm{Ca}$ values were converted to subsurface temperatures using a species-specific $G$. tumida temperature calibration (Mohtadi et al., 2011). The age model is based on gamma ray attenuation density correlation with nearby Ocean Drilling Program (ODP) Site 851 (M. Lyle, pers. comm., 2015).

\section{Results}

During the early Pliocene $(\sim 5 \mathrm{Ma})$, subsurface temperatures at Site U1338 (Fig. F2) were $\sim 4.5^{\circ} \mathrm{C}$ warmer than the modern temperature $\left(17.2^{\circ} \mathrm{C}\right)$. Subsurface temperatures steeply cooled by $\sim 4^{\circ} \mathrm{C}$ between 4.0 and $4.8 \mathrm{Ma}$ and gradually cooled an additional $\sim 0.5^{\circ} \mathrm{C}$ toward the present day. Figure $\mathrm{F} 3$ shows smoothed, locally weighted $( \pm 10 \%)$ least-squares subsurface temperatures from Site U1338 and ODP Leg $138\left(110^{\circ} \mathrm{W}\right)$ Sites 848, 849, and 853. Nonsmoothed records for Sites 848, 849, and 853 can be found in Ford et al. (2012). Smoothed records are shown here for ease of comparison to show the regional cooling pattern throughout the eastern equatorial Pacific.

\section{Acknowledgments}

Samples were provided by the Integrated Ocean Drilling Program (IODP). Thanks are given to R. Franks for analytical support. We thank A. Klaus and G. Delgado for editorial support and P.S. Dekens for reviewer comments. Funding for analyses was pro- vided by OCE-1204254. B. Ramirez's undergraduate summer research experience was supported by the Lamont-Doherty Earth Observatory REU Program NSF grant OCE-1359194 and U.S. Science Support Program, IODP NSF grant OCE-1450528. Data are archived at https://doi.pangaea.de/10.1594/PANGAEA.884538.

\section{References}

Fiedler, P., and Talley, L., 2006. Hydrography of the eastern tropical Pacific: a review. Progress In Oceanography, 69(24):143-180.

https://doi.org/10.1016/j.pocean.2006.03.008

Ford, H.L., Ravelo, A.C., Dekens, P.S., LaRiviere, J.P., and Wara, M.W., 2015. The evolution of the equatorial thermocline and the early Pliocene El Padre mean state. Geophysical Research Letters, 42(12):4878-4887. https://doi.org/10.1002/2015GL064215

Ford, H.L., Ravelo, A.C., and Hovan, S., 2012. A deep eastern equatorial Pacific thermocline during the early Pliocene warm period. Earth and Planetary Science Letters, 355-356:152-161. https://doi.org/10.1016/j.epsl.2012.08.027

Martin, P.A., and Lea, D.W., 2002. A simple evaluation of cleaning procedures on fossil benthic foraminiferal $\mathrm{Mg}$ / Ca. Geochemistry, Geophysics, Geosystems, 3:1-8. https://doi.org/10.1029/2001GC000280

Mohtadi, M., Oppo, D.W., Lückge, A., DePol-Holz, R., Steinke, S., Groeneveld, J., Hemme, N., and Hebbeln, D., 2011. Reconstructing the thermal structure of the upper ocean: insights from planktonic foraminifera shell chemistry and alkenones in modern sediments of the tropical eastern Indian Ocean. Paleoceanography, 26(3):PA3219. https://doi.org/10.1029/2011PA002132

Rincón-Martínez, D., Steph, S., Lamy, F., Mix, A., and Tiedemann, R., 2011. Tracking the equatorial front in the eastern equatorial Pacific Ocean by the isotopic and faunal composition of planktonic foraminifera. Marine Micropaleontology, 79(1-2):24-40.

https://doi.org/10.1016/j.marmicro.2011.01.001

Rosenthal, Y., and Lohmann, G.P., 2002. Accurate estimation of sea surface temperatures using dissolution-corrected calibrations for $\mathrm{Mg} / \mathrm{Ca}$ paleothermometry. Paleoceanography, 17(3):16-1-16-6. https://doi.org/10.1029/2001PA000749

Steph, S., Tiedemann, R., Groeneveld, J., Sturm, A., and Nürnberg, D., 2006. Pliocene changes in tropical east Pacific upper ocean stratification: response to tropical gateways? In Tiedemann, R., Mix, A.C., Richter, C., and Ruddiman, W.F. (Eds.), Proceedings of the Ocean Drilling Program, Scientific Results, 202: College Station, TX (Ocean Drilling Program), 1-51. https://doi.org/10.2973/odp.proc.sr.202.211.2006

Steph, S., Tiedemann, R., Prange, M., Groeneveld, J., Schulz, M., Timmermann, A., Nürnberg, D., Rühlemann, C., Saukel, C., and Haug, G.H., 2010. Early Pliocene increase in thermohaline overturning: a 
precondition for the development of the modern equatorial Pacific cold tongue. Paleoceanography, 25(2):PA2202. https://doi.org/10.1029/2008PA001645

Wara, M.W., Anderson, L.D., Schellenberg, S.A., Franks, R., Ravelo, A.C., and Delaney, M.L., 2003. Application of a radially viewed inductively coupled plasma-optical emission spectrophotometer to simultaneous measurement of $\mathrm{Mg} / \mathrm{Ca}, \mathrm{Sr} / \mathrm{Ca}$, and $\mathrm{Mn} / \mathrm{Ca}$ ratios in marine bio- genic carbonates. Geochemistry, Geophysics, Geosystems, 4(8):8406. https://doi.org/10.1029/2003GC000525

Initial receipt: 23 August 2017

Acceptance: 18 January 2018

Publication: 26 February 2018

MS 320321-220 
Figure F1. Sea-surface temperature map of the eastern equatorial Pacific.

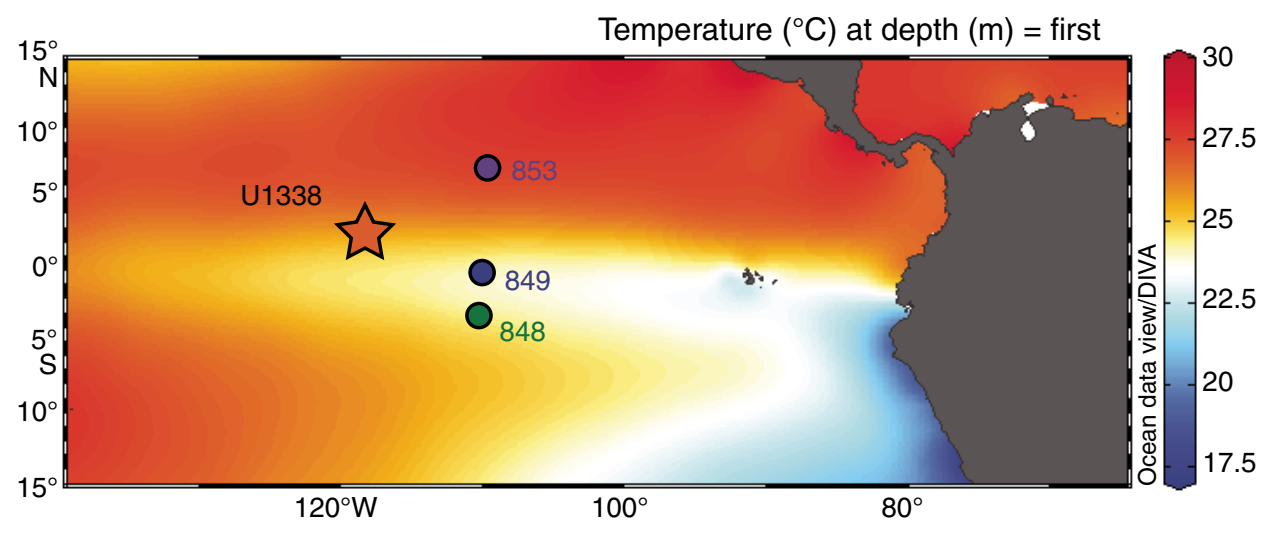

Figure F2. $\mathrm{Mg} / \mathrm{Ca}$ values and subsurface temperature reconstruction using Globorotalia tumida from Site U1338. Red star $=$ modern temperature at $100 \mathrm{~m}$ water depth $\left(17.2^{\circ} \mathrm{C}\right)$. Thick lines $=$ locally weighted $( \pm 10 \%)$ leastsquares smoothing.

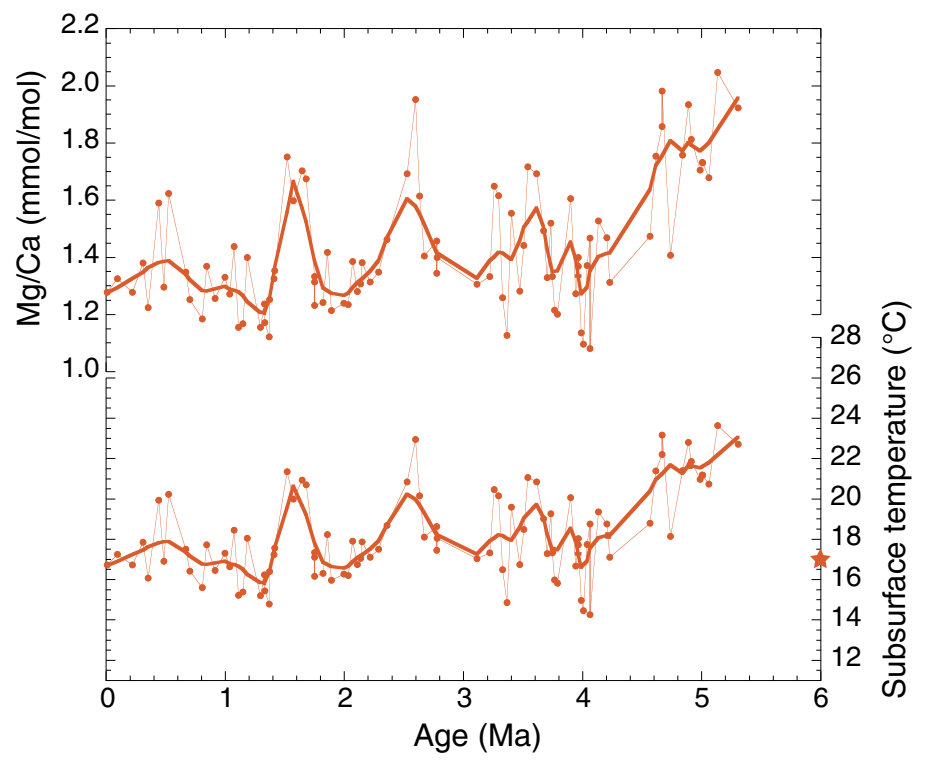


Figure F3. Comparison of locally weighted $( \pm 10 \%)$ least-squares smoothed subsurface temperatures from the eastern equatorial Pacific region. Sites 848, 849, and 853 (Ford et al., 2012) steeply cooled from $\sim 4.8$ to $4.0 \mathrm{Ma}$ and gradually cooled toward the present day.

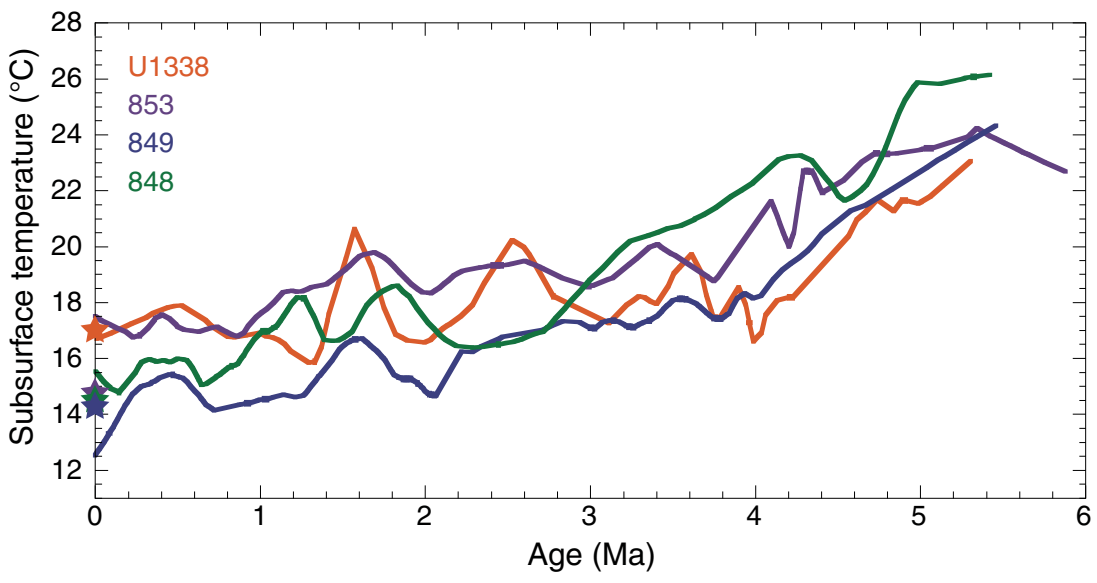

